УДК 376-056:27-725-46

DOI: $10.35619 /$ iiu.v1i14.395

Блавт Оксана

доктор педагогічних наук, професорка, професорка кафедри фізичного виховання Національного університету «Львівська політехніка», м. Львів, Україна ORCID: 0000-0001-5526-9339 e-mail: oksanablavt@ukr.net

\title{
ІННОВАЦІЙНІ ПЕДАГОГІЧНІ ПІДХОДИ У РОЗВИТКУ ІНКЛЮЗИВНОГО СЕРЕДОВИЩА ДЛЯ ЗДОБУВАЧІВ - ВЕТЕРАНІВ ВІЙНИ ЗАСОБАМИ АДАПТИВНОЇ ФІЗИЧНОЇ КУЛЬТУРИ
}

\begin{abstract}
Анотація. У статті проаналізовано питання розвитку інклюзивного середовища для ветеранів війни у закладах вищої освіти. Актуальність дослідження обумовлена значними проблемами щодо збереження здоров'я ветеранів війни у масштабі всієї держави, спричинених бойовими діями на сході країни. Мета дослідження - виявлення інноваційних педагогічних підходів у розвитку інклюзивного середовища для ветеранів війни у закладах вищої освіти засобами адаптивної фізичної культури. Установлено, що одним із найважливіших завдань адаптивної фізичної культури у вищій школі залишається забезпечення високого рівня здоров'я, працездатності, функціональних можливостей i фізичної підготовленості здобувачів-ветеранів війни. Виявлено напрями інноваційних педагогічних підходів у розвитку інклюзивного середовища для здобувачів - ветеранів війни у закладах вищої освіти засобами адаптивної фізичної культури. Вони передбачають поліпшення фізичного простору закладу вищої освіти, забезпечення спеціальними технічними та навчально-методичними засобами фізичного виховання, облаштування для проведення корекційно-розвиткових i реабілітаційних занять; удосконалення кадрового забезпечення: підвищення рівня професійної компетентності педагогів; розроблення навчальних програм з урахуванням потреб здобувачів - ветеранів війни, організації групових і колективних занять з адаптивної фізичної культури, використання гнучких стратегій i методів адаптивної фізичної культури, їх корекційного спрямування та здоров'язбережувальної спрямованості.

Ключові слова: інклюзивне середовище, заклад вищої освіти, ветеран війни, адаптивна фізична культура.
\end{abstract}

Постановка проблеми. Українське суспільство вже кілька років поспіль перебуває у стані війни. Головною складовою соціальної взаємодії та інтеграції ветеранів війни, серед котрих немало осіб з інвалідністю, у 


\section{Інноватика у вихованні. Випуск 14. 2021.}

суспільстві є інклюзія. Інклюзивне освітнє середовище для ветеранів війни у закладах вищої освіти (ЗВО) як вагомий чинник модернізації освітнього процесу забезпечує збільшення ступеня їхньої участі в соціумі та передбачає можливість отримання якісних освітніх знань (Сакалюк та Александрова, 2016).

Передовсім, як і передбачено нормативними документами, зокрема Законом України «Про внесення змін до деяких законів України про освіту щодо організації інклюзивного навчання» (2014 р.), ветеранам війни має бути забезпечено доступ до системи вищої освіти та створено умови для іii здобуття як результату соціально-політичних змін, антидискримінаційних суспільних рухів i трансформацій традиційних поглядів на освіту соціально вразливих і незахищених верств суспільства (Сремина, 2016). Забезпечення повного і всеосяжного сприяння ветеранам війни у здобутті якісної освіти відповідно до особливостей, потреб і можливостей, $є$ одним із ключових пріоритетів сучасної української соціальної й освітньої політики, що додатково актуалізує означену проблему в зв'язку з бойовими діями на сході країни.

Аналіз останніх досліджень 3 проблеми. У зв'язку із потребою формування інклюзивного освітнього середовища для ветеранів війни у ЗВО дослідники вивчали цю проблематику у різних напрямах. Нині ця соціально-педагогічна проблема перебуває в полі зору академічної спільноти. Окрім того, науковий інтерес сфокусовано крізь призму міжнародної освітньої політики (Луговий та Таланова, 2013; Online education trends report, 2018; Maxwell, Granlund, and Augustine, 2018); через характеристику психолого-педагогічних аспектів в теорії і практиці освітнього процесу (Удич, 2018; Міщик, 2007); у виявленні особливостей організації інклюзивного середовища (Талдонова, 2018; Morley, Bailey, Tan, and Cooke, 2005) та використанні адаптивної фізичної культури (АФК) 3 такими здобувачами (Escartí, and Gutiérrez, 2010; Pogoda, Levy, Helmick, and Jo Pugh, 2017).

Згідно з інформацією (Shuba, \& Shuba, 2017) на сьогодні у вищій школі суттєво зросли та постійно піддаються цілеспрямованій трансформації кількість та якість накопичених змін. Особливо це помітно у створенні й розвитку інклюзивного середовища. Проте попри наявність цих досліджень у зазначеному напрямі практично відсутні розвідки, що стосуються саме ролі і місця у цьому процесі АФК. Доводиться констатувати, що інклюзивна інтеграція ветеранів війни засобами АФК часто має лише декларативний характер, а реаліями їхнього освітнього процесу й надалі залишаються доволі обмежені можливості реалізації фізичної активності у ЗВО, недоступність низки системи інклюзивних освітніх послуг для здобувачів-ветеранів війни, і як наслідок - низький рівень інклюзії таких здобувачів у середовищі закладу освіти.

Актуальність забезпечення ефективності АФК як чинника розвитку інклюзивного середовища у ЗВО для здобувачів-ветеранів війни значно зростає з огляду на те, що його формування має ключове значення у цьому 


\section{Інноватика у вихованні. Випуск 14. 2021.}

процесі, а отже для підготовки гармонійно розвинених, висококваліфікованих фахівців. Визначено, що АФК - один із провідних засобів відновлення розумової працездатності, що є надважливою умовою досягнення високих результатів у навчанні (Деделюк, 2014; Трояновська, 2018).

Визначена проблематика розглядається в загальнодержавному контексті, оскільки вона стосується категорії громадян, які в майбутньому мають скласти основу продуктивних сил суспільства. Це, своєю чергою, вимагає забезпечення їм якісної освіти відповідно до особливостей, потреб і можливостей. Зазначене стосується також обох складових формуючих АФК, а саме фізичної та психологічної підготовленості.

Аналіз літературних джерел, практики організації i методики реалізації занять з АФК зі здобувачами-ветеранами війни засвідчили існування суперечностей, що додатково актуалізують виокремлену проблему. А саме: між високим рівнем суспільних запитів до стану здоров'я майбутніх фахових спеціалістів i низьким практичним результатом. Важливість та необхідність формування якісного інклюзивного освітнього середовища для ветеранів війни у ЗВО, пов'язана 3 можливістю вдосконалювати зміст АФК у вищій школі, ураховуючи особливості такого контингенту здобувачів. Успішне розв'язання цього питання неможливе без використання інноваційних ідей та положень у формуванні й реалізації змісту АФК. Це сприятиме підвищенню ефективності цього процесу у аспекті досягнення якомога вищих результатів.

Мета статті - виявити інноваційні педагогічні підходи у розвитку інклюзивного середовища для ветеранів війни у ЗВО засобами АФК.

Методи дослідження: теоретичний аналіз, систематизація, порівняння різних поглядів на досліджувану проблему, узагальнення наявних відомостей з науково-методичної та спеціальної літератури.

Виклад основного матеріалу дослідження. Для проведення дослідження у визначеному напрямі з'ясуємо, що у розвинутих країнах інклюзивне середовище в освітніх установах загалом розглядають як ключовий чинник соціалізації у соціумі (Луговий, та Таланова, 2013). Перед освітньою спільнотою стоять нові виклики: забезпечення повноцінної можливості отримання вищої освіти учасниками бойових дій, а передовсім ветеранами війни, серед котрих чимало осіб з особливими потребами.

У нашому дослідженні ми також оперуємо поняттями, що закріплені у нормативній базі. Серед них - поняття «інклюзивне освітнє середовище», що розуміємо як «сукупність умов, способів і засобів їх реалізування для спільного навчання, виховної діяльності та розвитку здобувачів освіти 3 урахуванням їхніх потреб та можливостей» (Талдонова, 2018).

У сучасній вищій школі України інститут інклюзивного середовища розглядається як важливий компонент освітнього процесу, що забезпечує можливість для досягнення освітніх і професійних цілей здобувачів вищої 


\section{Інноватика у вихованні. Випуск 14. 2021.}

освіти з особливими освітніми потребами, якими у цьому разі є здобувачіветерани війни (Удич, 2018). Українські педагоги та міжнародні експерти зазначають, що в питанні розвитку інклюзивного навчання Україна зробила потужний крок вперед (Міщик, 2007).

Ми долучаємось до думки (Сремина, 2016), що реалізація освітнього процесу для ветеранів війни повинна відповідати належному рівню наукової організації з урахуванням усіх чинників Болонського процесу. У числі найважливіших напрямів освітньої роботи 3 цією категорією здобувачів виокремлюємо АФК. Із цим явищем сьогодні пов'язані численні очікування в розвитку системи комплексної інклюзії здобувачів-ветеранів війни.

Педагогічна практика вимагає створення відносно простого і водночас максимально універсального інструментарію АФК для здобувачів ветеранів-війни. У цьому контексті слід переглянути основні компоненти процесу: зміст, форми, методи, технології, методичне забезпечення АФК для такої категорії здобувачів. Вважаємо, що це потребує трансформації університетської інфраструктури у безбар'єрний освітній простір, завдяки чому реалізовується інклюзивна освітня політика для задоволення широкого діапазону освітніх, інформаційних та соціальних потреб ветеранів війни у ЗВО.

Визначено, що АФК - соціальний феномен, головною метою якого $€$ соціалізація людей з обмеженими фізичними можливостями, а не тільки їх лікування 3 допомогою фізичних вправ (Деделюк, 2014). Ціллю АФК є формування рухової активності біологічного і соціального фактора впливу на організм і особистість задля їх гармонізації для максимально можливої самореалізації в якості соціально та індивідуально значущого суб'єкту (Трояновська, 2018). Як зазначено, діяльність суб'єктів освітнього простору відбувається в умовах змін та підвищеної стресогенності середовища, що постійно змінюється (Луговий та Таланова, 2013), і саме процес адаптації потребує наявності у ветеранів війни резервів для забезпечення цієї діяльності.

Оскільки в Україні досвід практики формування інклюзивного освітнього середовища засобами АФК для ветеранів війни у ЗВО практично відсутній, вважаємо доцільним проаналізувати наявний зарубіжний досвід розвинених країн світу. Тож, оперуючи відкритою інформацією (Міщик, 2007; Escartí and Gutiérrez, 2010; Pogoda, Levy, Helmick and Jo Pugh, 2017), доходимо висновку, що зміст і завдання АФК здобувачів-ветеранів війни у ЗВО розвинених країнах світу реалізуються відповідно до таких напрямів:

освітній - забезпечує освоєння знань, формування і розвиток умінь $\mathrm{i}$ навичок з адаптивної фізичної активності, передбачених освітніми програмами для здобувачів-ветеранів війни, які навчаються за певними освітніми програмами з урахуванням рівня індивідуальних порушень;

реабілітаційний - спрямований на збереження і поліпшення стану здоров'я здобувачів-ветеранів війни (як фізичного, так і психічного), 


\section{Інноватика у вихованні. Випуск 14. 2021.}

адаптаційних можливостей організму, усунення, при можливості, наявних дисфункцій;

соціальний - передбачає адаптацію здобувачів-ветеранів війни до інклюзивного освітнього середовища, розвиток практичних умінь i навичок з адаптивної фізичної активності, що забезпечують їі соціалізацію та інтеграцію у соціум.

Надалі фізичну активність розглядали як комплексну характеристику індивіда, що потребує розвитку (вдосконалення) та передбачає наявність у нього бажання та потреби здійснювати фізичну діяльність, реалізація якої відбувається в різних формах і спрямована на вирішення завдань АФК (Zelenskyi and Zelenskyi, 2018). Натомість розвиток фізичної активності здобувачів-ветеранів війни повинен бути одним із пріоритетних завдань у розвитку інклюзивного середовища у ЗВО.

Здійснивши порівняльний аналіз, вважаємо, що АФК задля формування інклюзивного середовища у вищій школі має перейти до іншої освітньої парадигми. Ї̈̈ сутність полягає у тому, що фізична культура здобувачів-ветеранів війни стає процесом недирективним, iз фасилітаційним супроводом, а власне самоорганізованим i автономно розвивальним процесом. Одним із найважливіших завдань АФК залишається забезпечення високого рівня здоров'я, працездатності, функціональних можливостей i фізичної підготовленості здобувачівветеранів війни.

На основі цього аналізу встановлено, що забезпечення ефективності занять із АФК для здобувачів-ветеранів війни у ЗВО має спрямовуватися на:

соціалізацію здобувачів-ветеранів війни через взаємодію із педагогами та іншими здобувачами;

адаптацію здобувачів-ветеранів війни, які мають функціональні обмеження, до фізичних і соціальних умов освітнього середовища;

формування принципово нового світогляду, що базується на гуманістичних принципах, внаслідок чого відбувається якісне переосмислення та творче формування здобувачів-ветеранів війни;

розвиток основних фізичних і спеціальних якостей, підвищення функціональних можливостей органів і систем організму, та використання збережених рухових функцій у здобувачів-ветеранів війни;

сприяння промоції здорового способу життя, формування та посилення інтересу здобувачів-ветеранів війни до здоров'я шляхом проведення досліджень та організації освітніх, просвітницьких заходів, комунікативних кампаній, конференцій тощо у сфері здоров'язбереження на рівні університету.

За результатами нашої пошукової діяльності виокремлено педагогічні умови розвитку інклюзивного середовища для ветеранів війни у ЗВО засобами АФК: методичний супровід розвитку рухової активності здобувачів-ветеранів війни; урахування визначених мотивів і ситуативних чинників для забезпечення високої фізичної активності здобувачів- 


\section{Інноватика у вихованні. Випуск 14. 2021.}

ветеранів війни впродовж навчання; індивідуалізація засобів і методів залежно від їхнього фізичного стану. Перша умова забезпечує використання форм, засобів і методів АФК для досягнення розвивального ефекту у розвитку кожного компонента рухової активності; сформованості знань щодо фізичної активності; вияві функціональних можливостей основних систем організму; вияві фізичної працездатності; розвитку фізичних якостей; високого рівня здоров'я на основі формування навичок здорового способу життя.

Вибір поведінки, котру можна охарактеризувати як здоровий спосіб життя, має вирішальне значення для запобігання психічних розладів. Такого висновку дійшли вчені, дослідивши індивідуальні та комбіновані зв'язки між різними аспектами повсякденного життя і психічного здоров'я репрезентативного зразка здобувачів-ветеранів війни (Pogoda, Levy, Helmick and Jo Pugh, 2017).

Загальновідомо, що спосіб життя - це один із ключових чинників, який впливає на стан здоров'я. Доведено зв'язок між способом життя i здоров'ям людини - як фізичним, так і психічним (Zelenskyi and Zelenskyi, 2018). За період перебування на території проведення бойових дій ветеран війни жив в умовах постійного ризику, що може стати своєрідним каталізатором розладів психічної діяльності. Як наслідок безпосередньої участі у воєнних діях, при поверненні таких осіб до мирного середовища існує ймовірна загроза проявів сприйняття навколишнього середовища через «військову призму дійсності» (Сремина, 2016).

Систематичне урахування чинників, що формують здоров'я (фізичні вправи, шкідливі звички (куріння, алкоголь тощо), активний відпочинок тощо безпосередньо впливають на адаптивний імунітет, а їхня реалізація допоможе забезпечити здоровий спосіб життя кожного із здобувачів учасників бойових дій. Проте залишається проблема формування ціннісного ставлення здобувачів-ветеранів до здорового способу життя.

У будь-якій країні, що заснована на гуманістичних і демократичних принципах, здоров'я людини $\epsilon$ вищою цінністю, найважливішим надбанням держави, безперечним пріоритетом, запорукою життєстійкості і прогресу суспільства. Проаналізований досвід та узагальнені висновки свідчать, що АФК $є$ основним засобом створення можливостей для здобувачів-ветеранів війни отримати певний запас знань і умінь 3 метою подальшого їх застосування на практиці як протидію негативним для здоров'я проявам та особистісного удосконалення соціальних, розумових, емоційних, фізичних сфер буття.

Вважаємо, що інклюзивна освітня політика у ЗВО щодо здобувачівветеранів війни має бути цілеспрямованою діяльністю, скерованою на розвиток АФК на локальному університетському рівні. Ця діяльність має бути пов'язана з ухваленням дієвих нормативних актів та відповідальних рішень (наказів, інструкцій, рекомендацій) у галузі інклюзивної освіти задля інтегрованого використання усіх можливих засобів АФК. Безумовно, що розвиток «системи інклюзивних освітніх послуг» у ЗВО повинен 


\section{Інноватика у вихованні. Випуск 14. 2021.}

здійснюватися на основі регулярного оцінювання запитів осіб з іншими особливими освітніми потребами, якими є ветерани війни.

На основі опрацювання джерельної бази дослідження, а також інформації, отриманої в процесі здійснення наукової розвідки, окреслено напрями інноваційних педагогічних підходів до розвитку інклюзивного середовища для здобувачів-ветеранів війни засобами АФК. Вони зводяться до поліпшення фізичного простору ЗВО, забезпечення спеціальними технічними та навчально-методичними засобами навчання, облаштування місць для проведення корекційно-розвиткових і реабілітаційних занять; кадрового забезпечення - підвищення рівня професійної компетентності педагогів; розроблення навчальних програм 3 урахуванням потреб здобувачів-ветеранів війни, організації групових i колективних форм взаємодії, використання гнучких стратегій i методів навчання, їх корекційного спрямування. Зазначене передбачає й комплекс заходів здоров'язбережувальної спрямованості на формування інтересу здобувачів-ветеранів війни до занять фізичною культурою та спортом. Водночас розвиток інклюзивного освітнього середовища передбачає різноманітність технологій, які корелюються індивідуальним функціональним та емоційним станом (Maxwell, Granlund and Augustine, 2018). Такий інклюзивний підхід вимагає адаптованих стратегій АФК. Зокрема, потребує впровадження та розвитку адаптивного фізичного виховання, адаптивної рухової рекреації, креативних (художньомузичних) тілесно-орієнтованих практик, екстремальних видів рухової активності. Модифікація традиційних видів спорту та проведення факультативних заходів з фізичної активності є прикладами інклюзивного стилю АФК (Tant and Watelain, 2016) щодо залучення до активної участі здобувачів-ветеранів війни.

3 огляду на проведені дослідження, робимо висновок: існує необхідність перманентного моніторингу потреб здобувачів-ветеранів війни для занять у 3 ВО фізичною культурою в повному обсязі. Можлива організація на території університету окремої локації та забезпечення реальної можливості для здобувачів-ветеранів війни збиратися і провадити час разом; мобілізація ресурсів університету в галузі адаптивної фізичної активності та спорту для здійснення реабілітації тощо. Це потрібно для того, аби формувати спільно зі здобувачами-ветеранами війни їхню індивідуальну траєкторію фізичної активності з вибором видів, форм АФК, які можуть сприяти фізичному, соціальному та когнітивному розвитку як результату фізичної підготовки.

Зусилля науково-педагогічної спільноти слід спрямувати на обгрунтування і створення ефективних технологій адаптивної фізичної культури для здобувачів-ветеранів війни, які б забезпечували високий рівень фізичної активності суб'єктів освітнього процесу, оптимізації їх співпраці, досягненню прогнозованих результатів цього процесу. Висококваліфіковані педагоги повинні забезпечити оволодіння здобувачами-ветеранами війни спортивними цінностями (повага, чесна 


\section{Інноватика у вихованні. Випуск 14. 2021.}

гра, толерантність тощо), підтримувати їхні навички, впевненість, знання та розуміння для прийняття правильних рішень щодо фізичної активності впродовж усього життя, а також сприяти особистому благополуччю, здоровому та активному способу життя.

Реалізація конструктивних підходів до розвитку інклюзивного середовища для ветеранів війни засобами АФК у системі вищої освіти дає змогу подолати суперечності між задекларованою в нашій країні рівноправністю в отриманні освітніх послуг та фактичною лімітованістю можливостей користування цими правами для соціально вразливих груп українського суспільства.

Висновки і перспективи подальших розвідок. Нині українське суспільство зустрілося із завданням щодо соціальної інтеграції ветеранів війни в усі освітні галузі. Реалізація їхнього права на вищу освіту передбачає насамперед здійснення просвітницької діяльності та впровадження інноваційних методик в царині інклюзивної освіти.

Досліджено, що в Україні розвиток інклюзивного середовища для ветеранів війни у ЗВО знаходиться на початковому етапі та частково реалізується у контексті розвитку АФК. Однак виявлено відсутність використання потенціалу фізичної культури, що сприяє легкій адаптації здобувачів-ветеранів війни до функціонування академічного середовища закладу вищої освіти та підвищенню рівня навчальних результатів здобувачів вищої освіти.

Як підсумок, за результатами дослідження розширено наукові дані щодо необхідності розвитку інклюзивного середовища для ветеранів війни у ЗВО засобами АФК та має бути одним із пріоритетних завдань. Цьому сприятиме реалізація виокремлених педагогічних умов розвитку інклюзивного середовища для ветеранів війни засобами АФК: методичний супровід розвитку рухової активності здобувачів-ветеранів війни; урахування визначених мотивів і ситуативних чинників; індивідуалізація засобів і методів. Втім, це актуальна, складна проблема, яка потребує подальшого грунтовного дослідження.

Напрям подальших розвідок вбачаємо у проєктуванні програми розвитку інклюзивного середовища для ветеранів війни у ЗВО засобами АФК.

\section{СПИСОК ВИКОРИСТАНИХ ДЖЕРЕЛ}

Сакалюк, О. та Александрова, С. (2016). Розвиток освітнього середовища як технологія управління навчальним закладом в умовах інклюзії. Вісник Черкаського університет. Серія: Педагогічні науки. №13. С. 22-27.

Еремина, Т. (2016). Соціально-психологічна адаптація громадян, щзо брали участь $у$ військових діях. Міленіум. С. 120. URL: http://window.edu.ru/catalog/pdf2txt/270/50270/24619?p_page=1. [Дата звернення 03.08. 2021].

Луговий, В. та Таланова, Ж. (2013). Міжнародна й національні стандартні класифікації освіти: концепція і реалізація. Педагогіка і психологія. Вісник НАПН Украӥни: журнал Наи. акад. пед. наук Украӥни. № 1. С. 15-25. 


\section{Інноватика у вихованні. Випуск 14. 2021.}

Удич, 3. (2018). Формування предметно-просторового середовища інклюзивного освітнього середовища. Особлива дитина: навчання $i$ виховання: науковий, навчальний, інформаційний журнал. Київ: Педагогічна преса. №1(85). Січень-лютий-березень. С. 85-96.

Online education trends report (2018). URL: https://www.bestcolleges.com/perspectives/annual-trends-in-online-education/ [Дата звернення 03.08. 2021].

Maxwell, G., Granlund, M. and Augustine, L. (2018). Inclusion through participation: understanding participation in the international classification of functioning, disability, and health as a methodological research tool for investigating inclusion. Front. Educ. 3:e00041. https://doi.org/: 10.3389/feduc.2018.00041.

Міщик, Л.(2007). Інтеграція студентів різної інвалідності в освіту. Вісник Запорізького національного університету. № 1. СС. 131-136.

Талдонова, Л. (2018). Інклюзивне освітнє середовище. Теорія $і$ практика сучасної психології. № 6. СС. 97-101.

Morley, D., Bailey, R., Tan, J. and Cooke, B. (2005). Inclusive physical education: teachers' views of including pupils with special educational needs and/or disabilities in physical education. Eur. Phys. Educ. Rev. №11. PP. 84-107. https://doi.org/:10.1177/1356336X05049826.

Escartí, A. and Gutiérrez, M. (2010). Influence of the motivational climate in physical education on the intention to practice physical activity or sport. European Journal of Sport Science. № 9. PP. 1-12. https://doi.org/10.1080/17461390100071406.

Pogoda, T., Levy, C., Helmick, K. and Jo Pugh, M. (2017). Health services and rehabilitation for active duty service members and veterans with mild TBI. Brain Injury. №31(9). PP. 1220-1234. https://doi.org/10.1080/02699052.2016.1274777.

Shuba, L. and Shuba, V. (2017). Modernization of physical education of student youth. Physical education of students. № 21(6). PP. 310-316. https://doi.org/10.15561/20755279.2017.0608.

Деделюк, Н. (2014). Теорія і методика адаптивної фізичної культури. Луцьк: Вежа-Друк. 68 с.

Трояновська, М. (2018). Адаптивна фізична культура: навч.-метод. посіб. для студентів. Чернігів: Національний університет «Чернігівський колегіум» імені Т. Г. Шевченка. Чернігів. 104 с.

Zelenskyi, B. and Zelenskyi, R. (2018). Motivation: Attitude of Students of Higher Education Institutions of the III Accreditation Levels Toward Physical Education Classes. Teoriâ Ta Metodika Fizičnogo Vihovannâ. № 18(3). PP. 114-125. https://doi.org/10.17309/tmfv.2018.3.02.

Tant, M. and Watelain, E. (2016). Forty years later, a systematic literature review on inclusion in physical education (1975-2015): a teacher perspective. Educ. Res. Rev. № 19. PP. 1-17. https://doi.org/: 10.1016/j.edurev.2016.04.002.

\section{REFERENCES}

Sakaliuk, O. ta Aleksandrova, S. (2016). Rozvytok osvitnoho seredovyshcha yak tekhnolohiia upravlinnia navchalnym zakladom $v$ umovakh inkliuzii [Development of educational environment as a technology of school management in the conditions of inclusion]. Visnyk Cherkaskoho universytet. Seriia: Pedahohichni nauky. No 13. S. 2227. [in Ukrainian].

Yeremwna, T. (2016). Sotsialno-psykholohichna adaptatsiia hromadian, shcho braly uchast $\mathrm{u}$ viiskovykh diiakh. [Socio-psychological adaptation of citizens who take part in hostilities]. Milenium. S. $120 . \quad$ URL: 
http://window.edu.ru/catalog/pdf2txt/270/50270/24619?p_page=1. [Data zvernennia 03.08. 2021]. [in Ukrainian].

Luhovyi, V. ta Talanova, Zh. (2013). Mizhnarodna y natsionalni standartni klasyfikatsii osvity: kontseptsiia i realizatsiia. Pedahohika i psykholohiia [International and national standard classifications of education: concept and implementation]. Visnyk NAPN Ukrainy: zhurnal Nats. akad. ped. nauk Ukrainy. № 1. S. 15-25. [in Ukrainian].

Udych, Z. (2018). Formuvannia predmetno-prostorovoho seredovyshcha inkliuzyvnoho osvitnoho seredovyshcha. [Formation of subject-spatial environment of inclusive educational environment]. Osoblyva dytyna: navchannia $i$ vykhovannia: naukovyi, navchalnyi, informatsiinyi zhurnal. Kyiv: Pedahohichna presa. №1(85). Sichen-liutyi-berezen. S. 85-96. [in Ukrainian].

Online education trends report (2018). URL:

https://www.bestcolleges.com/perspectives/annual-trends-in-online-education/ [in English].

Maxwell, G., Granlund, M. \& Augustine, L. (2018). Inclusion through participation: understanding participation in the international classification of functioning, disability, and health as a methodological research tool for investigating inclusion. Front. Educ. 3:e00041. https://doi.org/: 10.3389/feduc.2018.00041. [in English].

Mishchyk, L. (2007). Intehratsiia studentiv riznoi invalidnosti v osvitu. [Integration of students with different disabilities into education]. Visnyk Zaporizkoho natsionalnoho universytetu. No 1. S. 131-136. [in Ukrainian].

Taldonova, L. (2018). Inkliuzyvne osvitnie seredovyshche [Inclusive educational environment]. Teoriia i praktyka suchasnoi psykholohii. No 6. S. 97-101. [in Ukrainian].

Escartí, A. \& Gutiérrez, M. (2010). Influence of the motivational climate in physical education on the intention to practice physical activity or sport. European Journal of Sport Science. Volume 9. PP. 1-12. https://doi.org/10.1080/17461390100071406. [in English].

Pogoda, T. K., Levy, C. E., Helmick, K. \& Jo Pugh, M. (2017). Health services and rehabilitation for active duty service members and veterans with mild TBI. Brain Injury. Volume 31(9). PP. 1220-1234. https://doi.org/10.1080/02699052.2016.1274777. [in English].

Shuba, L. \& Shuba, V. (2017). Modernization of physical education of student youth. Physical education of students. Volume 21(6). P. 310-316. https://doi.org/10.15561/20755279.2017.0608. [in English].

Dedeliuk, N. (2014). Teoriia i metodyka adaptyvnoi fizychnoi kultury. [Theory and methods of adaptive physical culture]. Lutsk: Vezha-Druk. 68 s. [in Ukrainian]

Troianovska, M. (2018). Adaptyvna fizychna kultura: navch.-metod. posib. dlia studentiv. [Inclusive educational environment]. Chernihiv: Natsionalnyi universytet "Chernihivskyi kolehium" imeni T. H. Shevchenka. Chernihiv. 104 s. [in Ukrainian].

Morley, D., Bailey, R., Tan, J., \& Cooke, B. (2005). Inclusive physical education: teachers' views of including pupils with special educational needs and/or disabilities in physical education. Eur. Phys. Educ. Rev. Volume 11. P. 84-107. https://doi.org/:10.1177/1356336X05049826. [in English].

Zelenskyi, B. and Zelenskyi, R. (2018). Motivation: Attitude of Students of Higher Education Institutions of the III Accreditation Levels Toward Physical Education Classes. Teoriâ Ta Metodika Fìičnogo Vihovannâ. No 18(3). P. 114-125. https://doi.org/10.17309/tmfv.2018.3.02. [in English].

Tant, M., \& Watelain, E. (2016). Forty years later, a systematic literature review on inclusion in physical education (1975-2015): a teacher perspective. Educ. Res. Rev. Volume 19. PP. 1-17. https://doi.org/: 10.1016/j.edurev.2016.04.002. [in English]. 


\title{
INNOVATIVE PEDAGOGICAL APPROACHES IN THE DEVELOPMENT OF AN INCLUSIVE ENVIRONMENT FOR WAR VETERANS IN HIGHER EDUCATION INSTITUTION BY MEANS OF ADAPTIVE PHYSICAL BALLS
}

\author{
Oksana Blavt \\ Doctor of Sciences (in Pedagogy), Professor, \\ Professor at the Department of Physical Education, \\ Lviv Polytechnic National University, \\ Lviv, Ukraine \\ ORCID: 0000-0001-5526-9339 \\ e-mail: oksanablavt@ukr.net
}

\begin{abstract}
The article considers the development of an inclusive environment for war veterans in higher education institutions. The relevance of the study is due to the significant problems in maintaining the health of war veterans on a national scale due to the fighting in the east of the country. The purpose of the research is to identify innovative pedagogical approaches in the development of an inclusive environment for war veterans in the higher education institution by means of adaptive physical culture. The research is based on the use of a set of general scientific theoretical methods: analysis, synthesis, systematization, generalization. It has been established that one of the most important tasks of adaptive physical culture in higher education is to ensure a high level of health, efficiency, functionality and physical fitness of war veterans. The directions of innovative pedagogical approaches in the development of an inclusive environment for war veterans in the higher education institution by means of adaptive physical culture are revealed. They consist of improving the physical space of the higher education institution, providing special technical and educational-methodical means of physical education, equipment for correctional and developmental and rehabilitation classes; staffing: raising the level of professional competence of teachers; development of curricula taking into account the needs of war veterans, organization of group and collective forms of interaction, use of flexible strategies and teaching methods, their correctional direction and health orientation. It was found that in Ukraine the development of an inclusive environment for war veterans in the higher education institution is at an early stage and is partially implemented in the context of the development of adaptive physical culture. There is a lack of use of the potential of physical culture, which contributes to the easy adaptation of students to the functioning of the academic environment of higher education and increase the level of learning outcomes of higher education.
\end{abstract}

Keywords: inclusive environment, higher education institution, war veterans, adaptive physical culture.

Стаття надійшла до редакиії 29.09. 2021 р. 